\title{
GERMAN VALIDATION OF THE PROSOCIAL AND AGGRESSIVE DRIVING INVENTORY (PADI)
}

\author{
Tanja Stoll, Mirjam Lanzer, Martin Baumann \\ Ulm University, Ulm, Germany \\ Email: tanja.stoll@uni-ulm.de
}

\begin{abstract}
Summary: This paper presents the German adaptation of the Prosocial and Aggressive Driving Inventory (PADI) (Harris et al., 2014). The self-report questionnaire measures safe (prosocial) and unsafe (aggressive) driving behavior. The questionnaire was translated using a forward-backward method. The translation clarity and its applicability were tested in a pilot study. The German version was then validated online with $N=291$ participants. Confirmatory factor analysis revealed the same factor structure as in the English original. Multiple regression analysis was employed to investigate existing connections between driving behavior and the Big Five personality traits. Aggressive driving behavior was associated with higher scores on Extraversion and lower scores on Agreeableness, Openness, and Conscientiousness. Prosocial driving behavior was associated with higher scores on Openness and Conscientiousness and with participants that were older and female. This questionnaire might be used to investigate effective forms of driving behavior.
\end{abstract}

\section{INTRODUCTION}

With the increasing development of automated driving, the driver's role will continue to change. However, people will still play a crucial role in the driver-vehicle system. Therefore, an important aspect in the development of automated vehicles is the driver's personality traits that might influence the perception of driving behavior. One instrument developed to investigate driver behavior is the Prosocial and Aggressive Driving Inventory (PADI). It is based on two scales, measuring both the safe (prosocial) and unsafe (aggressive) driving practices. Most instruments like the Driving Anger Expression Inventory (Deffenbacher, Lynch, Oetting, \& Swaim, 2002), the Dula Dangerous Driving Index (Dula \& Ballard, 2003) and others (Bone \& Mowen, 2006; Hennessy \& Wiesenthal, 2005) focus solely on unsafe driving behavior. While these approaches provide helpful insights into the aspects of unsafe driving, they lack any perspectives on effective forms of driving behavior. As Harris et al. (2014) point out, more questionnaires are needed that also focus on effective forms of driving that have an influence on accident prevention or cooperation with other road users. Therefore, the focus of the PADI is not only on risky or unsafe driving behavior but on prosocial aspects as well. Since there are only a few standardized questionnaires available in German regarding the aspects of effective driving behavior, this paper focuses on the German translation and validation of the PADI.

The PADI (Harris et al., 2014) is a self-report questionnaire consisting of 29 items: 17 for measuring prosocial and 12 for measuring aggressive driving behavior. It builds on the conceptual and methodological framework of the Aggressive Driving Behavior Scale (ADBS) (Houston, Harris, \& Norman, 2003). Aggressive driving, as measured in the PADI, is defined as "a pattern of unsafe driving behavior that puts the driver and others at risk" (Houston et al., 2003, p. 270). The risky driving aspects addressed by the PADI include speeding and expressing displeasure (rude 
gestures) but exclude violent behavior. The intention to harm others is not part of the questionnaire (Harris et al., 2014). Complementary to the definition of aggressive behavior, the concept of prosocial driving also emphasizes the behavior rather than the intent (Piliavin, Dovidio, Gaertner, \& Clark, 1981): It does not refer to the emotional state or the motivation but to actions of helping, sharing or cooperating. It is defined as "a pattern of safe driving behaviors that potentially protect the well-being of passengers, other drivers, and pedestrians, and that promotes effective cooperation with others in the driving environment" (Harris et al., 2014, p.2).

The PADI is based on the assumption that driving behavior is a relatively stable and enduring characteristic of a driver (Harris et al., 2014). Since several prior studies linked unsafe driving behavior to dimensions of the Five-Factor Model (Big Five) (Dahlen \& White, 2006; Schwebel, Severson, Ball, \& Rizzo, 2006; Taubman-Ben-Ari, Mikulincer, \& Gillath, 2004) Harris et al. (2014) correlated the PADI scales with the Big Five traits. Harris et al. (2014) found correlations between driving behavior and the personality traits of the Big Five as well as gender and age: Higher scores on Prosocial Driving were associated with higher scores on Agreeableness, Conscientiousness, and Openness. Participants that scored higher on Prosocial driving were more likely female and older. Regarding Aggressive Driving, it was found that higher scores on Aggressive Driving were associated with higher scores on Extraversion and with lower scores on Agreeableness, Conscientiousness, and Openness. Traffic accidents were more likely reported by participants who scored lower on Prosocial Driving and who were younger and female. Participants who reported traffic violations scored higher on Aggressive Driving and lower on Prosocial Driving.

We expected the German version of the PADI to be composed of the same two dimensions: "Prosocial Driving" and "Aggressive Driving". Moreover, we expected these two dimensions to be internally consistent and to show comparable correlations as in the English original regarding the Big Five, gender, age, and the reported accidents or tickets.

\section{METHOD}

\section{Translation of the PADI}

Based on the methods recommended by Bullinger et al. (1998), the PADI was translated into German by two independent translators. The two versions were then compared and combined into a new third version. This third version was translated back into English by a third translator and afterward compared to the initial English version regarding the meaning or each item. After some minor wording adaptation, - the third version was used for the questionnaire's validation.

\section{Participants}

Participants were recruited using social media, mailing lists, and flyers. Altogether 301 participants answered the online questionnaire. Participants were required to be German native speakers with a valid driving license. Nevertheless, ten subjects had to be excluded from calculations due to a lack of German knowledge or distorted answers (e.g., stating to be 120 years old). The remaining 291 (180 females) participants were between 18 and 63 years old $(M=28.26$ years; 
$S D=9.02$ years). In contrast to the original sample, our sample did not mainly consist of students. We raffled ten Amazon vouchers each amounting ten euros among all participants.

\section{Materials}

Personality measures. We used the German version of the NEO-Five-Factor Inventory (NEOFFI) (Costa \& McCrea, 1992) by Borkenau and Ostendorf (2008) to assess the Big Five personality dimensions (Neuroticism, Extraversion, Openness to experience, Agreeableness, Conscientiousness). Each dimension is measured with 12 items and takes on average ten minutes to fill in. In the original English version of the PADI (Harris et al., 2014), sensation seeking was also used to test the criterion validity. However, Harris et al. (2014) expressed doubts if sensation seeking is a motivator for aggressive driving in all its dimensions. Therefore, we decided to omit the sensation seeking scale.

Driving-related questions. Following the original version, the participants were asked if they committed any traffic violations (tickets received) over the past three years. If they confirmed receiving any tickets over the last three years, they were asked to indicate the reason why they were fined: Parking, speeding, failing to stop at a red traffic light, failing to maintain the minimum distance to the car ahead, or other. In Germany, based on a penalty points system, the Registry for Driving Aptitude records severe administrative offenses and felonies that affect road safety. We expected a higher correlation between the driver's record in the Registry for Driving Aptitude and Aggressive Driving as well as between "tickets received in the last three years" and Aggressive driving. The reason behind this is that "tickets" broadly cover also minor offenses (e.g., parking) while the penalty points supplement the fines in the case of more severe offenses. Therefore, the participants were also asked about the number of penalty points received in the last three years. As in the original English version of the PADI, the participants were also required to state the number of accidents in which they were involved over the past three years.

\section{Procedure}

An online questionnaire was created using Unipark. The questionnaire first informed participants that they were about to answer questions regarding driving behavior. After agreeing to the declaration of consent, the questionnaire started with the items of the NEO-FFI. It was then followed by the PADI and ended with the driving-related and demographical questions.

\section{RESULTS}

\section{Confirmatory factor analysis}

In the original version of the PADI, the two factors Prosocial and Aggressive driving behavior were identified. To test if the same structure is valid for the German translation we run a confirmatory factor analysis using a maximum likelihood estimation. An unsatisfactory fit of model was identified $\left(\chi^{2}(376)=688.85, p<.001, \mathrm{CFI}=.84, \mathrm{TLI}=.83\right.$, SRMI $\left.=.6, \mathrm{RMSEA}=.06\right)$. However, also the original questionnaire by Harris et al. (2014) had an unsatisfactory fit to the data before nine covariances were added to the model. Based on the modification indices we 
added covariances between the following items: 7 and 13, 26 and 27, 1 and 9, 5 and 8, 6 and 19, 3 and 25, 17 and 19, 12 and 25, 7 and 15 (for item names see Table 1).

After specifying the aforementioned nine covariances, the iteration of the model yielded an acceptable fit $\left.\chi^{2}(366)=531.681, \mathrm{p}<.001, \mathrm{CFI}=.92, \mathrm{TLI}=0.9, \mathrm{SRMR}=.06, \mathrm{RMSEA}=.04\right)$. This model is similar to the English original by Harris et al. (2014). Only item 6 had no significant influence.

\section{Principal component analysis}

To support the results of the confirmatory factor analysis we conducted a principal component analysis with varimax rotation of the 29 PADI items. The analysis yielded seven components with an eigenvalue over Kaiser's criterion of 1. A scree test (Cattell, 1966) supports a solution with two components. A two-factor solution accounted for $32.57 \%$ of the variance. Table 1 shows the loadings of each component: the first component loads high on prosocial driving, while the second loads high on aggressive driving. Prosocial driving behavior $(M=4.76 ; S D=$ 0.54 ) had a high reliability, Cronbach's- $\alpha=.84$. However, omitting item 6 would lead to an improvement by .02 . The Aggressive Driving behavior $(M=2.1 ; S D=0.59)$ also indicated a high reliability with Cronbach's- $\alpha=.79$.

Table 1. Item loading for principal component analysis with varimax rotation for the German translation of PADI items (Harris et al., 2014, p.3).

\begin{tabular}{|c|c|c|c|}
\hline No. & Item & $\mathrm{I}$ & II \\
\hline 1 & $\begin{array}{l}\text { Ich fahre in der Nähe von Fußgängern besonders vorsichtig (Drive with extra care around } \\
\text { pedestrians). }\end{array}$ & .634 & \\
\hline 11 & $\begin{array}{l}\text { Ich reduziere meine Geschwindigkeit in Baustellenbereichen (Slow down in a construction } \\
\text { zone). }\end{array}$ & .616 & -.146 \\
\hline 2 & $\begin{array}{l}\text { Ich passe besonders auf, wenn ich mich Kreuzungen nähere (Pay special attention when } \\
\text { approaching intersections). }\end{array}$ & .615 & -.109 \\
\hline 7 & $\begin{array}{l}\text { Ich verringere meine Geschwindigkeit, um mich schlechten Straßenverhältnissen anzupassen } \\
\text { (Decrease speed to accommodate poor road conditions). }\end{array}$ & .612 & -.229 \\
\hline 3 & $\begin{array}{l}\text { Ich fahre in der Nähe von Radfahrern besonders vorsichtig (Drive with extra care around } \\
\text { bicyclists). }\end{array}$ & .607 & -.103 \\
\hline 13 & $\begin{array}{l}\text { Ich fahre langsamer, um mich schlechten Witterungsverhältnissen anzupassen (Decrease } \\
\text { speed to accommodate poor weather conditions). }\end{array}$ & .589 & -.241 \\
\hline 4 & Ich passe auf, wenn ich abbiege (Pay special attention when making turns). & .583 & \\
\hline 9 & $\begin{array}{l}\text { Ich fahre vorsichtiger, um auf Fahrzeuge oder Menschen am Straßenrand Rücksicht zu } \\
\text { nehmen (z.B. langsamer fahren, Platz machen) (Drive more cautiously to accommodate } \\
\text { people or vehicles on the side of the road (e.g., slow down, move over). }\end{array}$ & .576 & \\
\hline 5 & $\begin{array}{l}\text { Ich passe auf den Verkehr und meine Umgebung auf, wenn ich fahre (Pay attention to traffic } \\
\text { and my surroundings while driving). }\end{array}$ & .571 & \\
\hline 16 & $\begin{array}{l}\text { Ich halte mich in Schulgebieten an die geltenden Geschwindigkeits-begrenzungen (Obey } \\
\text { posted speed limits in a school zone). }\end{array}$ & .562 & -.277 \\
\hline 8 & $\begin{array}{l}\text { Ich benutze beim Spurwechseln meine Rück- und Seitenspiegel und achte auf meinen toten } \\
\text { Winkel (Use mirrors and check blind spots when changing lanes). }\end{array}$ & .555 & \\
\hline 10 & $\begin{array}{l}\text { Ich halte den Sicherheitsabstand ein, wenn ich anderen Fahrzeugen folge (Maintain a safe } \\
\text { distance when following other vehicles). }\end{array}$ & .533 & -.315 \\
\hline 14 & $\begin{array}{l}\text { Ich lasse andere Verkehrsteilnehmer gewähren, wenn diese Vorfahrt haben (Yield when the } \\
\text { right of way belongs to other drivers). }\end{array}$ & .484 & -.169 \\
\hline 15 & Ich beachte Verkehrsschilder (Obey traffic signs). & .480 & -.167 \\
\hline 12 & Ich halte an Stoppschildern komplett an (Come to a complete stop at a stop sign). & .376 & -.181 \\
\hline 17 & Ich benutze meinen Fahrtrichtungsanzeiger (Blinker), um andere Verkehrsteilnehmer auf & .374 & -.283 \\
\hline
\end{tabular}


27 Ich hupe, wenn ein Fahrer etwas Unangebrachtes macht (Honk when another driver does something inappropriate).

19 Ich beschleunige, wenn andere Verkehrsteilnehmer versuchen mich zu überholen (Speed up when another vehicle tries to overtake me).

20 Ich fahre dicht an das vorausfahrende Fahrzeug auf, um andere Fahrzeuge daran zu hindern sich vor mir einzufädeln (Follow the vehicle in front of me closely to prevent another vehicle from merging in front of me).

22 Ich fädele mich auch dann in den Verkehr ein, wenn ein anderer Fahrer versucht die Lücke zwischen den Fahrzeugen zu schließen (Merge into traffic even when another driver tries to close the gap between vehicles).

28 Ich überhole andere Fahrzeuge auf der rechten Spur (Pass other vehicles using the right lane).

26 Ich benutze beleidigende Gesten, wenn Verkehrsteilnehmer etwas machen, was mit nicht gefällt (Make rude gestures at other drivers when they do something I do not like).

24 Ich fahre mindestens $25 \mathrm{~km} / \mathrm{h}$ schneller als die vorgegebene Geschwindigkeitsbegrenzung (Drive 15 miles per hour faster than the posted speed limit).

29 Ich folge mit weniger als einer Autolänge Abstand langsameren Verkehrsteilnehmer (Follow a slower vehicle at less than a car length).

21 Ich schere vor anderen Fahrzeugen mit weniger als einer Autolänge Abstand ein (Pass in front of a vehicle at less than a car length).

23 Ich beschleunige an einer Kreuzung, wenn die Lichtsignalanlage (Ampel) von Gelb auf Rot springt (Accelerate into an intersection when the traffic light is changing from yellow to red).

18 Ich wechsele oft zwischen den Fahrspuren, um andere Verkehrsteilnehmer zu überholen (Weave in and out of lanes to overtake traffic).

6 Ich tippe die Bremse leicht an, um Fahrer hinter mir zu warnen (Break slowly enough to alert drivers behind me).

\section{Logistic regression}

To examine criterion validity, we conducted three logistic regression analyses (see Table 2). Involvement in accidents and traffic violations were dichotomized.

Table 2. Logistic regressions predicting accidents, violation (tickets and penalty points)

\begin{tabular}{lcccc}
\hline & $\mathrm{r}$ & $\mathrm{B}$ & $\mathrm{SE}$ & $\mathrm{e}^{\mathrm{B}}$ \\
\hline Predicting Accidents & & & & $.559^{*}$ \\
Prosocial Driving Scale & $-.148^{*}$ & -0.581 & 0.279 & 0.925 \\
Aggressive Driving Scale & .038 & -0.078 & 0.251 & 1.241 \\
Gender & -.038 & 0.216 & .282 & $.944^{* *}$ \\
Age & $-.184^{* *}$ & -0.057 & .022 & $34.589^{*}$ \\
Constant & & 3.544 & 1.694 & .659 \\
Predicting violations (tickets) & & & .291 & $2.534^{* *}$ \\
Prosocial Driving Scale & $-.189^{* *}$ & -0.417 & .288 & .938 \\
Aggressive Driving Scale & $.259^{* *}$ & 0.930 & .279 & $1-008$ \\
Gender & .081 & -0.064 & .015 & .099 \\
Age & .003 & 0.007 & 1.709 & $.410^{*}$ \\
Constant & & 0.539 & & 1.353 \\
Predicting violations (penalty points) & & & .390 & 0.701 \\
Prosocial Driving Scale & $-.201^{* *}$ & -0.892 & .340 & 0.995 \\
Aggressive Driving Scale & $.147^{*}$ & 0.302 & .392 & 5.598 \\
Gender & .098 & -0.356 & .026 & 2.263 \\
Age & -.502 & -0.005 & 1.722 & \\
Constant & & & & \\
\hline
\end{tabular}

$* p<.05 * * p<.01$. 


\section{Multiple regression}

We also conducted two multiple regression analyses to investigate the influence of the Big Five Scales, gender and age on the PADI scales (results in Table 3).

Table 3. Multiple regressions predicting PADI scales with the NEO-FFI, gender, and age

\begin{tabular}{|c|c|c|c|c|c|c|}
\hline Scale statistics & Predicti & ocial D & & Predictin & essive I & \\
\hline & $\mathrm{R}^{2}$ & $\mathrm{r}$ & $\beta$ & $\mathrm{R}^{2}$ & $\mathrm{r}$ & $\beta$ \\
\hline Constant & $.214 * * *$ & & & $.172 * * *$ & & \\
\hline Age & & .187 & $.164 * *$ & & -.063 & -.040 \\
\hline Gender & & -.196 & $-.129 *$ & & .208 & $.128^{*}$ \\
\hline Conscientiousness & & .312 & $.234 * * *$ & & -.168 & $-.128 *$ \\
\hline Agreeableness & & .271 & $.166^{*}$ & & -.296 & $-.254 * * *$ \\
\hline Extraversion & & .048 & -.079 & & .082 & $.194 * *$ \\
\hline $\begin{array}{l}\text { Neuroticism } \\
\text { Openness }\end{array}$ & & $\begin{array}{l}-.087 \\
.216\end{array}$ & $\begin{array}{l}-.061 \\
.168^{* *}\end{array}$ & & $\begin{array}{l}.-039 \\
-.198\end{array}$ & $\begin{array}{l}.008 \\
-152 *\end{array}$ \\
\hline
\end{tabular}

$* \mathrm{p}<.05 * * \mathrm{p}<.01 * * * \mathrm{p}<.001$.

\section{DISCUSSION}

The purpose of this study was the translation and validation of the German adaptation of the PADI. Harris et al. (2014) developed this instrument with the intention to contribute to research that promotes safety for drivers, pedestrians, and other road users. The confirmatory factor analysis supported the two factors interpretation with a satisfying internal consistency. There is only one item that fails to support the structure (Item 6), results showing a higher internal consistency of the Prosocial scale without this item. Therefore, we recommend its omission in future questionnaires. With logistic regressions, some findings by Harris et al. (2014) were replicated. Older participants reported fewer accidents in the last three years while a significant negative interaction was found between Prosocial Driving and reported accidents in the last three years. Prosocial Driving behavior is only a significant predictor for a record in the Registry while Aggressive Driving behavior is only a significant predictor for received tickets. Against our assumption, the correlation between Aggressive Driving and a record in the Registry was lower than the correlation between Aggressive Driving and received tickets. Nevertheless, both correlations were significant. We could not find a significant connection between gender and reported accidents in the last three years. Regarding the multiple regression, most findings of Harris et al. (2014) were replicated: Higher scores on Prosocial driving are more likely reported by participants who scored higher on Openness, Agreeableness, and Conscientiousness, who were older and female While higher scores on Aggressive Driving Behavior were more likely reported by participants who scored higher on Extraversion and who scored lower on Openness, Conscientiousness, and Agreeableness and who were male.

In conclusion, it is reasonable to assume that the German validation of the PADI was successful. Future investigations would benefit from a combination of self-reported Prosocial Driving behavior and observable driving behavior. The PADI might be a helpful questionnaire for further research on driving styles and cooperative driving for autonomous vehicles. 


\section{ACKNOWLEDGMENTS}

This project was funded within the Priority Programme "CoInCar - Cooperatively Interacting Automobiles" of the German Science Foundation DFG.

\section{REFERENCES}

Bone, S. A., \& Mowen, J. C. (2006). Identifying the traits of aggressive and distracted drivers: A hierarchical trait model approach. Journal of Consumer Behaviour: an International Research Review, 5, 454-464.

Borkenau, P., \& Ostendorf, F. (2008). NEO-Fünf-Faktoren Inventar: nach Costa u. McCrae; NEO-FFI: Hogrefe, Verlag f. Psychologie.

Bullinger, M., Alonso, J., Apolone, G., Leplège, A., Sullivan, M., Wood-Dauphinee, S., . . Bech, P. (1998). Translating health status questionnaires and evaluating their quality: the IQOLA project approach. Journal of Clinical Epidemiology, 51, 913-923.

Cattell, R. B. (1966). The scree test for the number of factors. Multivariate Behavioral Research, $1,245-276$.

Costa, P. T., \& McCrea, R. R. (1992). Revised neo personality inventory (neo pi-r) and neo fivefactor inventory (neo-ffi): Psychological Assessment Resources.

Dahlen, E. R., \& White, R. P. (2006). The Big Five factors, sensation seeking, and driving anger in the prediction of unsafe driving. Personality and Individual Differences, 41, 903-915.

Deffenbacher, J. L., Lynch, R. S., Oetting, E. R., \& Swaim, R. C. (2002). The Driving Anger Expression Inventory: A measure of how people express their anger on the road. Behaviour Research and Therapy, 40, 717-737.

Dula, C. S., \& Ballard, M. E. (2003). Development and Evaluation of a Measure of Dangerous, Aggressive, Negative Emotional, and Risky Driving 1. Journal of Applied Social Psychology, 33, 263-282.

Harris, P. B., Houston, J. M., Vazquez, J. A., Smither, J. A., Harms, A., Dahlke, J. A., \& Sachau, D. A. (2014). The prosocial and aggressive driving inventory (PADI): a self-report measure of safe and unsafe driving behaviors. Accident; Analysis and Prevention, 72, 1-8.

Hennessy, D. A., \& Wiesenthal, D. L. (2005). Driving vengeance and willful violations: Clustering of problem driving attitudes. Journal of Applied Social Psychology, 35, 61-79.

Houston, J. M., Harris, P. B., \& Norman, M. (2003). The Aggressive Driving Behavior Scale: Developing a self-report measure of unsafe driving practices. North American Journal of Psychology, 5, 269-278.

Piliavin, J. A., Dovidio, J. F., Gaertner, S., \& Clark, RD, III. (1981). Emergency intervention. New York.

Schwebel, D. C., Severson, J., Ball, K. K., \& Rizzo, M. (2006). Individual difference factors in risky driving: The roles of anger/hostility, conscientiousness, and sensation-seeking. Accident Analysis \& Prevention, 38, 801-810.

Taubman-Ben-Ari, O., Mikulincer, M., \& Gillath, O. (2004). The multidimensional driving style inventory - scale construct and validation. Accident Analysis \& Prevention, 36, 323-332. 